\title{
Income Structure, Profitability and Stability in the Tunisian Banking Sector
}

\author{
Houda Belguith $^{1}$, Meryem Bellouma ${ }^{2}$ \\ GEF2A lab, ISG Tunisia, University of TUNIS, TUNISIA \\ GEF2A lab, Faculty of Economic and Management of Nabeul, TUNISIA
}

\begin{abstract}
This study examines the effect of revenue diversification across and within interest and non-interest income on bank stability and performance in Tunisian banks over the period 2001-2014. Using panel estimations and instrumental variables approach to handle the endogeneity problem of diversification variables. We find that revenue diversifications among and within interest and non-interest revenue generating operations boost bank profitability and stability. Our findings suggest also that the benefits from diversification are largest for banks with more shifts to nontraditional banking business lines (investment banking) while, absent for banks which follow cross-selling strategies of financial services.
\end{abstract}

Keywords - bank performance, bank stability, interest income, non-interest income, Tunisian Banks.

\section{INTRODUCTION}

The banking industry in both developed and developing countries has experienced important shifts that have been related to its increasing deregulation and competition. This has led banking institutions to diversify their income generating activities toward non-interest income operations. Unsurprisingly, the share of the classical financial intermediation operations has decline in both developed and developing banking industries. While the major source of income for banks is interest revenue from credits to customer, new banking business lines which generate non-interest revenue, have emerged such as fee generating activities, trading securities, investment banking and other operations.

The effects of shifts toward non-traditional banking activities on bank performance and stability have been widely examined in developed economies while rarely addressed in developing economies. There has been no large consensus in the empirical literature regarding the impact of the shift toward non-interest income generating operations on bank performance and risk in developed countries. For instance, Stiroh (2004a, 2004b, 2006), Stiroh and Rumble (2006) and Lepetit and al. (2008) find that non-interest activities positively affect bank performance but negatively impact bank stability. This is because noninterest income generating operations are highly volatile. However, diverging results have been found in the context of developing countries (Sanya and Wolfe, 2011; Nguyen and al., 2012; Pennathur and al., 2012). Thus, one of the aims of this study is to contribute to the limited literature that analyzes the impact of bank's income diversification on performance and stability in the context of developing economies. As this group of countries presents different features compared to developed countries mainly in terms of banking regulatory framework and maturity and structure of the banking sector, we would expect to find different effect of income diversification on bank performance and risk.

The recent financial crisis has shown that banking supervisors should be concerned with banks' business models in addition to the classical prudential norms such that bank capitalization, liquidity and risk management. The analysis of banks' business models which signals the way in which banks generate profits and serve customers can provide banking supervision authorities with a deeper understanding of the sustainability of bank performance and stability (Köhler, 2015).

The recent financial crisis has showed that not all banks were impacted equally. The effect of the crisis has been related to the business model chosen by each bank. Banks with traditional banking model, mainly those relying on the classical financial intermediation function, faced huge losses (ECB, 2010). In fact, banks with high rates of loan growth have reported a significant decrease in their performance during the recent financial crisis. For instance, in Europe, the return-on-equity (ROE) of EU banks with the highest average rate of loan growth within the period 2003-2006 dropped, on average, from $13.34 \%$ in 2006 to $6.77 \%$ in 2008 . However, the ROE of banks with the lowest loan growth rates decreased less importantly from $10.46 \%$ to $5.65 \%$. Interestingly, in 2009, while the performance of the first group of EU banks declined further, the ROE of the second group of banks (with the lowest rates of loan growth) increased (Köhler, 2015). Thus, if we consider the decline in banks' profitability as an indicator of risk-taking, we would argue that banks with high growth rate in terms of lending activity have incurred greater risks than those with low growth rate of their lending activities.

While large banks with high share of non-interest income have also faced large losses during the recent financial crisis, small banks relying on non-interest banking activities have benefited from diversification of their income sources as it has allowed them to be less dependent on overall business condition and therefore to be more stable (Liikanen, 2012). 
In this study, we use detailed information on interest and non-interest income categories as well as on their components for a sample of 11 banks over the period 2001-2014. We try to answer the question regarding which business models allow for high profitability gains for banks and which ones expose banks to higher return volatility and instability. To do so, we examine the effect of business models on bank stability and performance. We test whether banks become more stable in case they increase their non-interest banking activities due to the effect of the diversification of revenue sources. We also examine whether this positive effect of the diversification of banking activities depends on the type of both interest and non-interest incomes and on their correlation. In addition, we try to answer the question of which banks are taking much more benefits from revenue diversification through controlling for bank funding and ownership structures.

Our findings indicate that revenue diversification through a shift toward non-interest income generating activities leads to higher performance and risk-adjusted profitability of Tunisian banks. This result confirms the findings of Sanya and Wolfe (2011), Pennathur and al. (2012) and Meslier and al. (2014) who find a positive association between income diversification and bank performance in emerging countries. Furthermore, our results show that diversification gains are more pronounced in banks where non-interest income are generated from nontraditional banking business lines while absent in those following cross-selling strategy of their financial products to a core business customers.

This work has two main motivations. The first motivation comes from the diverging findings with regard to the relationship between revenue diversification and bank performance and stability in emerging economies. Indeed, this study explores this gap in the literature in an emerging country. The second motivation of this study stems from the fact that it has been shown that some types of banks with different kinds of business models proved to be vulnerable during the recent financial crisis (Mergaerts and Vennet, 2016). Thus, this work aims at reconsidering banks' business models in the direction of strengthening the resilience of banks.

This work contributes to the existing literature in two important ways. First, contribute to the related empirical literature by using the instrumental variables approach to handle the problem of endogeneity of the diversification variables. This is because we believe that the income diversification decision of banks can be thought as being itself impacted by bank performance. This might be the case when, for instance, poorly performing banking institutions decide, under the pressure of their shareholders, to diversify their income structure to reduce their overall risk. Second, we complement the existing literature on banks' business models by analyzing the effect of the subcategories of interest income and non-interest income on bank stability and performance. This is because previous studies have shown that not every type of the interest and noninterest income is equally volatile or has the same impact on bank performance and stability (DeYoung and Torna, 2013; Stiroh, 2007).

The remainder of this paper is organized as follow. Section 2 discusses the related literature and formulates the hypotheses to be tested. Section 3 presents the data and the econometric methodology. Section 4 shows the descriptive analysis. Section 5 presents our findings. Finally, section 6 concludes.

\section{LITERATURE REVIEW AND HYPOTHESIS}

The empirical literature on banking stability argues that excessive growth rates of lending activity lead to higher risk taking by banks (Foos and al., 2010; Jimenez and Saurina, 2006). However, the effect of bank's business mix on bank stability has not been demonstrated clearly. For instance, while many authors argue that an increase in non-interest banking activities, like for instance investment banking, allows banks to benefit from additional sources of income and to diversify their overall revenue which would make them more stable, others argue that bank instability may arise when banks diversify their income sources by relying on non-interest activities due to the higher volatility of these activities. Busch and Kick (2009) suggest that the volatility of banks' profitability significantly increases when they become involved in fee business.

However, Chiorazzo and al. (2008) finds that an increase of the share of non-interest income by Italian banks will lead to higher risk-adjusted returns. For the case of Germany, Busch and Kick (2009), show that savings and cooperative banks will have their performance improved if they increase their share of non-interest income, while the authors find no impact of noninterest income on the profitability of commercial banks. For developing countries, there are also findings which suggest that banks benefit from a better revenue diversification (Sanya and Wolfe, 2011).

Mergaerts and Vennet (2016) argue that the diversification of income structure should lead to better trade-off between the expected level and variance of banks' performance. Of course, for this positive effect of income source diversification to hold, banks' income-generating operations should not be perfectly correlated. A bank's business model that relies on income diversification allows banks to generate more non-interest income from the average asset, which more than compensates the lower level of net interest income and higher expenses. However, Stiroh and Rumble (2006) and Demirgüc-Kunt and Huizinga (2010) show that income diversification has a positive impact on profitability, but a negative one on bank stability. 
Altunbas and al. (2011) and Köhler (2015) find that more diversified banks are generally less likely to be under stress. Lepetit and al. (2008) argue that revenue diversification toward non-interest income generating activities can lower the cyclical variations in profits if incomes across bank activities are not perfectly correlated. Further, income diversification leads to increased competitive pressures between banks across a large number of banking business lines which can increase innovation and efficiency in the provision of banking services.

\subsection{H1: Revenue diversifications across and within interest and non-interest revenue generating operations enhance bank performance and stability.}

DeYoung and Torna (2013) find that banks which diversify into non-interest income are less likely to encounter financial distress. Further, the authors argue that the effect of non-interest income on bank stability significantly depends on the type of non-interest income. While a larger share of revenue from asset-based non-traditional banking operations, such as investment banking and asset securitization, is found to make financially distressed banks significantly more likely to fail, a larger share of fee-based non-traditional banking activities, such as insurance sales, significantly decreases the probability of a failure.

The authors examine, in the context of the recent financial crisis, whether banks with a larger share of non-interest income were more likely to fail. They find that it is not non-interest revenue per se that made banks more likely to fail, but rather the type of non-interest income. More specifically, the authors show that a larger share of income from asset-based nontraditional activities, such as investment banking and asset securitization, has led to higher banks failures. However, the authors argue that a larger share of fee-based non-traditional activities such as insurance sales has reduced the probability of failure during the financial crisis.

It is important to note that a shift toward non-interest revenue that stems from traditional banking activities may not lead to diversification benefits. Instead, it may, lead to a reduction of diversification benefits. This is because this type of income is subject to the same variations as interest-generating activities which might lead to further volatility of banks' benefits. This is the case when banks follow cross-selling strategy through providing financial products to a core customer base. However, diversification benefits are higher when a bank shifts toward non-interest revenue generated from nontraditional banking operations.

In addition, it may be the case that both categories of income coming from traditional and nontraditional baking activities are uncorrelated but both highly volatile. The standard portfolio theory argues that the overall variance of operating income increases when the variations of revenues stemming from both traditional and nontraditional banking operations increase (Meslier el al., 2014).

2.2 H2: An increase in non-interest income generated from nontraditional banking activities enhance bank stability, while those generated from traditional banking activities worsen bank stability.

Many papers have examined the impact of the diversification of income and funding sources on bank risk and return. Demirgüc-Kunt and Huizinga (2010) find some risk diversification benefits at very low shares of non-interest income and non-deposit funding. However, for the most banks, they find that increases in the shares of both non-interest revenue and non-deposit funding are associated with higher instability. Altunbas and al. (2011) find that banks with a more diversified income structure are more stable.

Köhler (2015) argues that the way in which banks diversify their income and funding sources impacts their risk and profitability. The author suggests that this impact depends on the business model chosen by each bank. For instance, for retail-oriented banks, while a shift towards non-interest revenue leads to higher stability and performance, an increase in the share of non-deposit funding is associated with bank instability. This is because such business strategy will make them less dependent on interest banking activities which improves their risk diversification and, therefore, leads to more stability and profitability. However, for investment-oriented banks, while a shift towards non-interest revenue leads to higher instability, an increase in the share of non-deposit funding leads to more significant stability. This is because these banks, with such business model, already have higher share of non-interest income and a further increase in it will limit the benefits of diversification of income sources as it leads to over diversification.

Lepetit and al. (2008) and Mercieca and al. (2007) show that European banks that have increased their non-interest income operations are more risky than banks that mainly supply loans.

However, the related literature argues that the opposite sign of the relationship between revenue diversification and bank performance may also occur. Mercieca and al. (2007) argue that when banks over expand their operations toward new market segments where they face higher competition or lack of expertise, revenue diversification may worsen bank performance. 
The authors indicate that there is a threshold or a risk optimal level that diversifying beyond it may lead to an increased idiosyncratic risk for banks.

\subsection{H3: Revenue diversification positively impact bank performance but up to a given threshold.}

Altunbas and al. (2011) show also that larger banks and those with higher growth rates of loans are more risky, while stable banks are those characterized by a strong deposit base. Demirgüc-Kunt and Huizinga (2010) obtain similar findings. They show that banks which are mostly relying on fee and trading income are less stable. The authors indicate also that banks which are heavily relying on wholesale funding are more risky. However, Demirgüc-Kunt and Huizinga (2010) find no evidence that high growth rate of loans leads to higher risk-taking by banks.

Recent studies have argued that a higher reliance on customer deposits decreases bank distress (Altunbas and al., 2011; Betz and al., 2013) and inspires market confidence (Beltratti and Stulz, 2012). Mergaerts and Vennet (2016) find that banks characterized by a traditional funding structure are both more profitable and stable. The authors show that a higher deposit ratio is associated with lower interest expenses, which leads to higher net interest income and greater returns. Further, banks with business model characterized by a higher share of customer deposits are also better able to generate non-interest income due to the greater scope of cross-selling products to an expanded group of retail clients, which can raise fee income.

The literature on the bank capital argues that the use of equity as a funding source of banks decreases the ability of banks' creditors to exert market discipline (Diamond and Rajan, 2001). However, equity financing may induce banks to monitor borrowers more intensively (Mehran and Thakor, 2010). Beltratti and Stulz (2012) find that during the recent financial crisis, banks with business models that rely on higher capital ratios performed better and were less likely to encounter severe distress. These banks had higher levels of net interest margins and return on assets, but this did not suffice to offset the mechanical negative impact on return on assets. The positive impact of such business model on ROA and NIM can mainly be attributed to lower interest expenses. This can be explained by the fact that the use of a higher capital ratio decreases banks' reliance on interest-bearing funding sources.

Mergaerts and Vennet (2016) find that banks which rely on high capital ratios have significantly higher Z-scores and therefore are more stable. However, the authors also confirm the results of Delis and al. (2014), who find that a higher capital ratio increases ROA volatility which leads to bank risk. Nevertheless, their results show that the positive impact of a higher capital ratio on ROA more than offset the positive effect on ROA volatility. These findings support the strengthening of the capital rules by Basel III and the continuous pressure of supervisory authorities on banks to increase capital ratios.

\subsection{H4: The impact of revenue diversification on stability in more pronounced in under capitalized banks.}

The literature that analyzes the influence of different types of ownership on the profitability of banks also draws divergent conclusions. While some empirical studies show that foreign banks are more efficient (Ahmad 2017, Meselier 2014), others find evidence that public banks are more efficient (Das and Ghosh, 2010). Microco et al. (2007), for industrialized countries, found no evidence to support the idea that private banks are more profitable than public banks. However, they have found support for developing countries. In addition, Iannotta et al. (2007) argue that public banks are less profitable than their counterparts because of the increased risk associated with project financing. On the other hand, Dietrich and al, (2011) argue that Swiss public banks are more profitable than private banks during the financial crisis. Chen and Liu (2013) show that the performance of banks varies by ownership structure, with public and foreign banks playing a more unfavorable role than private banks.

\subsection{H5: Revenue diversification gains are more pronounced in private banks.}

The empirical literature on bank stability argues that, in addition to banks' income and funding structure, there are many other variables that affect bank stability. For instance, Köhler (2015) argues bank stability is positively associated with capitalization but negatively correlated with bank scale. Also, the author finds that a higher rate of asset growth makes banks significantly more risky, while a higher net interest margin and a larger loan portfolio is found to reduce bank risk.

Regarding the impact of bank size on the relationship between banks' business models and bank stability, Köhler (2015) finds that smaller banks will be significantly more stable if they generate a larger share of their income from non-traditional activities, but will be instable if they increase their share of non-deposit funding. The author also finds that larger banks will have significantly less volatile returns if they increase their share of non-interest income. 


\section{DATA AND ECONOMETRIC METHODOLOGY}

\subsection{Data and variables définition}

The bank-specific data used in this study stem from the Thomson Reuters Eikon database. The sample contains the eleven largest banks operating in Tunisia which represent together a market share of more than $88 \%$ of the total assets of the Tunisian banking sector. The period of study is 2001-2014. We have, therefore, a dataset which contains 154 bank-year observations for each variable.

There has been a huge discussion in the empirical literature regarding how to measure bank risk-taking as one proxy for banking stability. In this study, we follow the empirical related literature (Altunbas and al., 2011; Demirgüc-Kunt and Huizinga, 2010; Köhler, 2015) and use as a proxy for bank stability the variable Z-Score which is defined as follows:

$$
Z-\text { score }_{i t}=\left(\frac{R O A_{i t}+C A R_{i t}}{\sigma_{R O A i}}\right)
$$

Where:

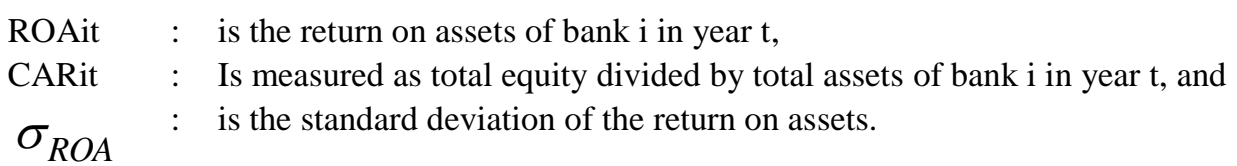

The variable Z-Score is computed as the sum of the ROA and the ratio of total equity to total assets divided by the standard deviation of ROA. This measure indicates how many standard deviations that a bank's return on assets has to fall for the bank to become insolvent. Z-Score indicates the distance to insolvency. It can be used as a good indicator of bank risk (Delis and al., 2014). A higher level of $Z$-score means a lower bank risk. However, a lower value indicates higher riskiness.

Mergaerts and Vennet (2016) interpret Z-score as a measure of the distance-to-default as it represents the number of standard deviations ROA can diverge from its mean before the bank defaults. The authors argue that Z-score should be used as a distress indicator, rather than as a direct measure of bank risk-taking. This is because we have seen a decrease in the observed evolution of Z-score for European banks during the recent financial crisis instead of before it.

There has been a huge debate in the empirical literature regarding how to identify banks' business models. For instance, Mergaerts and Vennet (2016) argue that there are two approaches of business model identification. The first approach allocates banks to specific groups using direct or indirect classification. While the direct classification uses qualitative variables (e.g. the bank type according to regulation) that are assimilated to the business model, the indirect classification combines the information regarding a set of continuous variables to construct distinct groups of observations that are as homogeneous as possible (Ayadi and al., 2011, 2012; Martín-Oliver and al., 2015; Roengpitya and al., 2014). However, this approach based on classification can be criticized for the validity of its hypothesis that there exist clearly separable business models which means the non-existence of intermediate strategies. The Tunisian banking sector has been characterized since 2001 , by very limited regulations in what concerns the scope of bank activities. The enactment of the banking law $n^{\circ} 2001-$ 65 of 10 July 2001 has introduced the concept of universal bank which can operate as commercial and investment bank at the same time.

The second approach suggested by the related literature (Altunbas and al., 2011; Demirgüc-Kunt and Huizinga, 2010) directly relates individual business model features to bank performance. This approach allows us to identify the specific characteristics of a business model that improve bank performance and stability. One drawback of this strategy is that it is unable to directly identify the effect of the business model, because it does not clearly define how the individual features are interrelated to compose a business model. In this research, we choose the second approach by using a set of indicators that capture a bank's strategic choices related to the income and liability structure. These specific variables are presented below.

In this study, we define banks' business models by taking into account the level of diversification of both income sources and funding sources. This is done through examining the share of non-interest revenue in total operating revenue and the share of non-deposit funding in total bank's liabilities. The related empirical literature has identified many banks' business models. For instance, banks which mostly provide lending and deposit-taking services for households and SMEs have a more retailoriented business model. These banks are typically smaller. On the other hand, investment-oriented banks are those which 
have a large share of their revenue generated through non-traditional banking activities such that investment banking and trading. These banks are typically larger and fund most of their activities on wholesale markets (Köhler, 2015).

Köhler (2015) indicates that business models show how banks generate profits, what customers they serve and which distribution channels they use. Therefore, examining business models goes beyond looking at classical indicators of bank risk and performance and should give banking supervisors a deeper understanding of the sustainability of bank profits and stability. In this study, we describe a bank's business model by the structure of its income and funding. We proxy the income structure using the ratio of non-interest income over total operating income (NII) and the funding structure using the ratio of non-deposit funding over total liabilities (NDF).

The previous studies have shown that banks' income structure as it is measured using the share of both non-interest income and interest income to total operating income, has a significant impact on bank performance and stability. Also, banks' funding structure measured by the share of both non-deposit funding and customer deposits to total liabilities, has been shown to affect bank performance and stability. Nevertheless, as we argue that not every type of non-interest income and interest income is equally volatile or has the same impact on bank performance and stability (DeYoung and Torna, 2013; Stiroh, 2007), we opt in this study, for analyzing the subcategories of the aforementioned variables instead of taking into consideration their aggregate values. We are able to implement such subdivisions in our analysis since the data are available in the Thomson Reuters Eikon database.

For the analysis of income structure, we take into consideration four subcategories of interest income and six subcategories of non-interest income. We subdivide interest income into (1) interest on loans, (2) interest on investment securities, (3) interest on deposits and (4) other interest income. For non-interest income, we take into consideration the following subcategories: (1) fees and commissions from operations, (2) dealer trading account profit, (3) investment securities gains, (4) insurance commissions, fees and premiums, (5) foreign currencies gains and other non-interest income. Then we measure the importance of each subcategory of interest and non-interest income with respect to total operating income.

In what concerns the analysis of the funding structure, we take into consideration three items, namely, (1) equity, (2) customer deposits and non-deposit funding. Then we measure the importance of each subcategory with respect to total assets.

In addition to the diversification variables, we use a set of control variables related to bank-specific factors (bank size, capitalization, loan growth, and deposit growth and bank efficiency) and macro-economic condition (GDP growth and inflation rate).

We use efficiency indicator as we believe that the way a bank manage its expenses does impact its performance. EFFICIENCY is computed as the ratio of non-interest expenses to total revenue less interest expenses and it measures the cost to the bank of each unit of revenue. Belaid and Bellouma (2016) use the ratio of operating expenses divided by operating incomes as one control variable that is not directly related to business model but is important to determine bank performance and stability. This ratio measures banks' cost inefficiency and reflects bank managers' skills in terms of controlling and monitoring their operating expenses where a high value of this ratio indicates high cost inefficiency.

\subsection{Econometric methodology}

A detailed dataset is used in this study on eleven Tunisian banks over 14 years (from 2001 to 2014) for a total 154 bank-year observations. We start our empirical analysis by panel data estimation. We regress our dependent variables which measure bank risk-adjusted performance, namely, risk-adjusted ROA (RAROA) and risk-adjusted ROE (RAROE) and bank's insolvency risk (Z-score) on a set of variables related to revenue diversification across and within interest and non-interest income. We use also a set of bank specific variables including bank size, capitalization, loan and deposit growth rates and bank efficiency. In addition, we control for macroeconomic factors by taking into consideration GDP growth and inflation rate.

Thus, we estimate the following model:

$$
Y_{i t}=\alpha+X_{i t}+Z_{i t}+\theta_{t}+\varepsilon_{i t}
$$

Where:

Y represents: 
RAROAit : risk-adjusted return on assets computed as ROA divided by its standard diviation.

RAROEit : risk-adjusted return on equity computed as ROE divided by its standard diviation.

Z-Scoreit : defined as the sum of ROA and the ratio of total equity to total assets divided by the standard deviation of ROA.

$\mathrm{X}$ represents a set of our variables of interest that indicate the bank's revenue diversification through shifts across interest and non-interest generating operations and within these two types of income:

HHI_REVit: measures the revenue diversification between interest and non-interest income.

NIIit: measures the share on non-interest income in total operating income..

HHI_NIIit: measures the diversification within non-interest income generating activities.

HHI_IINit: measures the diversification within interest income generating activities.

$\mathrm{Z}$ represents a set of bank specific control variables:

EQUITYit: measures bank capitalization using the ratio of equity to total assets.

DEPOSITSit: is computed as deposits from customers divided by total assets.

NDF it: is calculated as the ratio of non-deposit funding over total assets.

SIZEit: measures bank size using the logarithm of total assets.

EFFICIENCYit: is the ratio of non-interest expenses to total revenue less interest expenses and it measures the cost to the bank of each unit of revenue.

LOAN_G it: measures the annual growth in total loans.

DEPOSIT_G it: measures the annual growth in total deposits.

$\theta$ Represents macroeconomic variables:

GDPt: annual GDP growth rate.

INFt: inflation rate.

As we are using panel data, both fixed and random effects models can be used. While random effects model considers that the variation across individuals is assumed to be random and uncorrelated with the regresses included in the model, fixed effects does not. We run Husman test in order to determine our appropriate method of estimation.

The result of the test of Hausman shows a p-value which is greater than the 5\%. Thus, we use random effects method as we cannot reject the null hypothesis.

In a second stage of our empirical analysis, and for robustness checks, we use an instrumental variables (Two-Stage least squares, 2SLS) regression. This econometric choice is motivated by the fact that our revenue diversification variables may be endogenous which leads to an inconsistency of the estimators. Indeed, a problem of reverse causality between bank performance and revenue diversification may exist which can cause an endogeneity problem in our explanatory variables of interest. This is because we believe that the revenue diversification decision can be thought as being itself affected by bank performance. This might be the case when, for instance, poorly performing banking institutions decide, under the pressure of their shareholders, to diversify their income structure. To solve this problem of endogeneity we use the instrumental variable approach. To do so, we choose new variables as instruments for our diversification indicators. These instruments have to satisfy the two important properties of being exogenous (not correlated with the error term) and largely correlated with the endogenous variables. Following Maudos and Solis (2009) and Meslier and al. (2014), we use as instruments the lagged levels of our diversification variables in order to handle the endogeneity problem.

\section{DESCRIPTIVE ANALYSIS}

In this section, we present a brief overview of banks' income structure in the Tunisian banking sector. Table 1 provides the descriptive statistics for the variables used in this study and Table 2 shows the pair wise correlation matrix.

In what concerns bank profitability, Table 1 shows the low level of ROA and ROE for Tunisian banks compared to the average values in emerging countries (Sanya and Wolfe, 2011). In addition, an important feature of bank performance to be highlighted is the high within volatility of bank performance over the period 2001-2014. Surprisingly, the within variations of ROA and ROE are greater than the between variations. This bank performance feature indicates the high instability of bank performance in Tunisia. For the risk-adjusted return on assets (RAROA) and on equity (RAROE) and the insolvency risk (Z-Score), the between bank variation is higher than the within bank variation which means that there is a large heterogeneity across banks included in our sample that should be examined further. For these variables, the mean and the median values are close to each other which indicate that the data are not skewed, so we do not need to use the logarithmic scales of it. 


\section{TABLE 1}

DESCRIPTIVE STATISTICS OF THE VARIABLES USED IN THIS STUDY

\begin{tabular}{|c|c|c|c|c|c|}
\hline & \multirow{2}{*}{ Mean } & \multirow{2}{*}{ Median } & \multicolumn{3}{|c|}{ Standard deviation } \\
\hline & & & Within & Between & Overall \\
\hline \multicolumn{6}{|l|}{ Bank performance } \\
\hline Return on Assets (ROA) & 0.011 & 0.012 & 0.012 & 0.008 & 0.014 \\
\hline Return on Equity (ROE) & 0.041 & 0.091 & 0.379 & 0.112 & 0.394 \\
\hline \multicolumn{6}{|l|}{ Bank Stability } \\
\hline Risk adjusted ROA (RAROA) & 2.444 & 2.281 & 0.967 & 2.105 & 2.234 \\
\hline Risk adjusted ROE (RAROE) & 1.734 & 1.184 & 0.967 & 1.899 & 2.058 \\
\hline Insolvency Risk (Z-Score) & 23.336 & 23.453 & 7.018 & 16.876 & 17.603 \\
\hline \multicolumn{6}{|l|}{ Income Diversification } \\
\hline Interest Income/Total Op. Income (IIN) & 0.719 & 0.709 & 0.063 & 0.071 & 0.092 \\
\hline Non-Interest Income/Total Op. Income (NII) & 0.281 & 0.291 & 0.063 & 0.071 & 0.092 \\
\hline Diversification between IIN and NII (HHI_REV) & 0.613 & 0.587 & 0.066 & 0.068 & 0.092 \\
\hline \multicolumn{6}{|l|}{ Diversification within Interest Income } \\
\hline Diversification within Interest Income (HHI_IIN) & 0.925 & 0.990 & 0.067 & 0.069 & 0.094 \\
\hline Interest on Loans (INT_LOANS) & 0.959 & 0.995 & 0.038 & 0.038 & 0.053 \\
\hline Interest on Deposits (INT_DEPOSITS) & 0.011 & 0 & 0.016 & 0.013 & 0.021 \\
\hline Interest on Investments Securities (INT_INVEST) & 0.017 & 0 & 0.023 & 0.020 & 0.029 \\
\hline Other Interest Income (INT_OTHER) & 0.013 & 0 & 0.021 & 0.017 & 0.026 \\
\hline \multicolumn{6}{|l|}{ Diversification within Non-Interest Income } \\
\hline Diversification within Non-Interest Income (HHI_NII) & 0.467 & 0.447 & 0.122 & 0.089 & 0.149 \\
\hline Fees from operations (FEES) & 0.519 & 0.521 & 0.121 & 0.133 & 0.176 \\
\hline Profit from trading (TRADE) & 0.109 & 0 & 0.096 & 0.130 & 0.157 \\
\hline Gains from investment securities (INVEST) & 0.206 & 0.185 & 0.082 & 0.193 & 0.202 \\
\hline Insurance fees (INSUR) & 0.009 & 0 & 0.036 & 0.024 & 0.043 \\
\hline Foreign currencies gains (FX) & 0.019 & 0 & 0.039 & 0.036 & 0.052 \\
\hline Other Non-Interest Income (NII_OTHER) & 0.137 & 0.068 & 0.114 & 0.107 & 0.153 \\
\hline \multicolumn{6}{|l|}{ Bank Specific Controls } \\
\hline Equity (EQUITY) & 0.113 & 0.086 & 0.052 & 0.087 & 0.097 \\
\hline Customer Deposits (DEPOSITS) & 0.718 & 0.768 & 0.076 & 0.153 & 0.165 \\
\hline Non-Deposit Funding (NDF) & 0.168 & 1.149 & 0.045 & 0.085 & 0.093 \\
\hline Log assets (SIZE) & 7.589 & 7.744 & 1.350 & 0.727 & 0.779 \\
\hline Efficiency (EFFICIENCY) & 0.535 & 1.549 & 0.143 & 0.119 & 0.183 \\
\hline Loan Growth (LOAN_G) & 0.099 & 0.089 & 0.081 & 0.024 & 0.084 \\
\hline Deposit Growth (DEPOSIT_G) & 0.132 & 0.099 & 0.199 & 0.141 & 0.240 \\
\hline
\end{tabular}

Notes: ROA is the return on assets measured as net income before taxes over total assets. ROE is the return on equity calculated as net income over total equity. RAROA and RAROE are the measures of risk-adjusted return on assets and equity, respectively. Z-score is calculated as the sum of ROA and the ratio of total equity to total assets divided by the standard deviation of ROA. IIN is computed as interest income divided by total operating income. NII is computed as non-interest income divided by total operating income. HHI_REV measures income diversification between IIN and NII (using the Herfindahl Hirschman Index). HHI_IIN measures the diversification within interest revenue generating operations. INT_LOANS, INT_DEPOSIT, INT_INVEST and INT_OTHER measure, respectively, the share of interest on loans, interest on deposits, interest on investment securities and other interest income in total interest revenue. HHI_NII measures the diversification within non-interest revenue generating operations. FEES, TRADE,

INVEST, INSUR, FX and NII_OTHER measure the share of, respectively, fees generated from banking operations, gains on trading securities, profits from the sale of investment securities, fees and premium earned from taking or brokering insurance policy subscriptions, foreign currency trading gains and other non-interest income in total non-interest revenue. EQUITY measures the ratio of total equity over total assets. Deposits measure the ratio of total deposits over total assets. NDF is the ratio of non-deposit funding over total assets. Size is the logarithm of total assets. EFFICIENCY is computed as the ratio of non-interest expenses to total revenue less interest expenses and it measures the cost to the bank of each unit of revenue. LOAN_G and DEPOSIT_G measure the annual growth in total loans and total deposits, respectively.

Table 1 shows that $72 \%$ of the total operating income of Tunisian banks stems from interest-income generating activities, while $28 \%$ are generated from non-interest income operations. This indicates that financial intermediation function remains the core banking business of Tunisian banks. The concentration on bank income towards interest generating operations is confirmed by the level of the indicator Herfindahl Hirschman Index (HHI_REV) of 0.613 which close to the one observed in emerging economies (Sanya et Wolfe, 2011) of 0.62. The between and within variations of this indicator are close to each other which indicates a similar behavior of Tunisian banks regarding their diversification strategy of revenue between interest income and non-interest income activities.

Regarding the diversification within interest income generating activities, we notice a very large concentration towards interest on loans to customers with a share of $96 \%$. This is confirmed by the high value of the indicator HHI_IIN of 0.925 . So far, we conclude that the financial performance and stability of Tunisian banks is highly dependent on their lending activities' behavior and therefore their stability is determined by the quality of their loan portfolios. 
TABLE 2

Pairwise Correlation Between The VARiables USEd In This STUdY

\begin{tabular}{|c|c|c|c|c|c|c|c|c|c|c|c|c|c|c|c|c|c|c|c|c|}
\hline & RAROA & RAROE & $\begin{array}{l}\text { Z- } \\
\text { SCORE }\end{array}$ & $\begin{array}{l}\mathrm{HHI}_{-} \\
\mathrm{REV}\end{array}$ & IIN & NII & $\begin{array}{l}\text { HHI_ } \\
\text { IIN }\end{array}$ & HHI_NII & $\begin{array}{l}\mathrm{INT}_{-} \\
\text {LOANS }^{-}\end{array}$ & \begin{tabular}{|l} 
INT_- $_{-}$ \\
DEPOSI \\
TS
\end{tabular} & $\begin{array}{l}\text { INT } \\
\text { INVEST }\end{array}$ & FEES & TRADE & INVEST & $\begin{array}{l}\text { INSU } \\
\mathrm{R}\end{array}$ & FX & $\begin{array}{l}\text { EQUIT } \\
\text { Y }\end{array}$ & $\begin{array}{l}\text { DEPOSI } \\
\text { TS }\end{array}$ & NDF & $\begin{array}{l}\text { SIZ } \\
\text { E }\end{array}$ \\
\hline RAROA & 1 & & & & & & & & & & & & & & & & & & & \\
\hline \begin{tabular}{|l|} 
RAROE \\
\end{tabular} & $0.86 * * *$ & 1 & & & & & & & & & & & & & & & & & & \\
\hline \begin{tabular}{|l|} 
Z-SCORE \\
\end{tabular} & $0.65^{* * * *}$ & $0.46^{* * * *}$ & 1 & & & & & & & & & & & & & & & & & \\
\hline HHI_REV & $-0.26^{* * * *}$ & -0.12 & $0.25 * * *$ & 1 & & & & & & & & & & & & & & & & \\
\hline IIN & $\mid-0.35 * * *$ & $\mid-0.16^{* * *}$ & 0.07 & $0.96^{* * *}$ & 1 & & & & & & & & & & & & & & & \\
\hline NII & $0.35^{* * * *}$ & 0.16 *** & \begin{tabular}{|l|l|}
-0.07 \\
\end{tabular} & \begin{tabular}{|l|l|}
$-0.96 * * * *$ \\
\end{tabular} & -1 & 1 & & & & & & & & & & & & & & \\
\hline HHI_IIN & -0.04 & \begin{tabular}{|l|}
-0.09 \\
\end{tabular} & 0.07 & -0.01 & -0.06 & 0.06 & 1 & & & & & & & & & & & & & \\
\hline \begin{tabular}{|l|} 
HHI_NII \\
\end{tabular} & 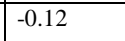 & \begin{tabular}{|l|}
-0.13 \\
\end{tabular} & $\mid 0.14 *$ & $0.39^{* * * *}$ & $0.36^{* * * *}$ & \begin{tabular}{|l|l|}
$-0.34 * * * *$ \\
\end{tabular} & $\mid-0.11$ & 1 & & & & & & & & & & & & \\
\hline \begin{tabular}{|l|} 
INT_LOANS \\
\end{tabular} & \begin{tabular}{|l|}
-0.04 \\
\end{tabular} & \begin{tabular}{|l|}
-0.08 \\
\end{tabular} & 0.07 & 0.00 & -0.05 & 0.05 & $0.91 * * *$ & \begin{tabular}{|c|c|}
-0.11 \\
\end{tabular} & 1 & & & & & & & & & & & \\
\hline \begin{tabular}{|l|} 
INT_DEPOSITS \\
\end{tabular} & $0.17^{* * *}$ & 0.13 & 0.10 & -0.17 ** & $-0.17 * *$ & 0.17 & $-0.73 * * *$ & \begin{tabular}{|c|c|}
-0.11 \\
\end{tabular} & \begin{tabular}{|l|l|}
$-0.75 * * * *$ \\
\end{tabular} & 1 & & & & & & & & & & \\
\hline INT_INVEST & \begin{tabular}{|l|}
-0.07 \\
\end{tabular} & 0.04 & \begin{tabular}{|l|}
-0.11 \\
\end{tabular} & $0.29^{* * * *}$ & $0.36^{* * * *}$ & $\mid-0.32^{* * * *}$ & $-0.61 * * *$ & $0.35^{* * * *}$ & $-0.60^{* * * *}$ & 0.08 & 1 & & & & & & & & & \\
\hline FEES & $\mid-0.38 * * *$ & $-0.20 * *$ & $-0.18 * *$ & $0.54^{* * * *}$ & $0.62 * * *$ & $\mid-0.62^{* * * *}$ & $-0.33 * * *$ & $0.75^{* * * *}$ & $-0.32 * * *$ & -0.02 & $-0.04 * * *$ & 1 & & & & & & & & \\
\hline TRADE & $\mid-0.21 * * *$ & $-0.20^{* * *}$ & \begin{tabular}{|l|}
-0.12 \\
\end{tabular} & $0.19^{* * *}$ & $0.15^{* *}$ & $-0.15 * *$ & $0.34 * * *$ & \begin{tabular}{|c|}
-0.08 \\
\end{tabular} & $0.333^{* * * *}$ & $-0.31 * * *$ & -0.12 & 0.0173 & 1 & & & & & & & \\
\hline \begin{tabular}{|l|} 
INVEST \\
\end{tabular} & 0.59 *** & $0.39^{* * * *}$ & $0.38^{* * * *}$ & \begin{tabular}{|l|l|}
$-0.42 * * * *$ \\
\end{tabular} & \begin{tabular}{|l|l|}
$-0.46^{* * * * *}$ \\
\end{tabular} & $0.46^{* * * *}$ & \begin{tabular}{|l|l|}
-0.04 &
\end{tabular} & \begin{tabular}{|l|}
-0.03 \\
\end{tabular} & -0.04 & $0.18^{* * *}$ & -0.12 & \begin{tabular}{|l|l|}
$-0.41^{* * * * *}$ \\
\end{tabular} & $-0.68^{* * * *}$ & 1 & & & & & & \\
\hline \begin{tabular}{|l|} 
INSUR \\
\end{tabular} & 0.17 ** & 0.04 & 0.05 & -0.10 & \begin{tabular}{|l|}
-0.07 \\
\end{tabular} & \begin{tabular}{|l|l}
0.07 \\
\end{tabular} & -0.12 & -0.27 **** & -0.12 & 0.31 **** & -0.12 & $-0.24 * * * *$ & $-0.33 * * *$ & 0.28 **** & \begin{tabular}{|l|}
1 \\
\end{tabular} & & & & & \\
\hline \begin{tabular}{|l|}
$F X$ \\
\end{tabular} & 0.02 & $0.30^{* * * *}$ & \begin{tabular}{|l|}
-0.12 \\
\end{tabular} & $-0.15^{*}$ & $-0.15^{*}$ & $0.15^{*}$ & $\mid-0.36^{* * * *}$ & $-0.21 * * *$ & -0.34**** & $0.46^{* * * * *}$ & $\begin{array}{l}-0.21 * * * * \\
\end{array}$ & \begin{tabular}{|l|}
-0.04 \\
\end{tabular} & $-0.18^{* * *}$ & \begin{tabular}{|c|}
-0.00 \\
\end{tabular} & $0.18^{* * *}$ & 1 & & & & \\
\hline \begin{tabular}{|l|} 
EQUITY \\
\end{tabular} & 0.03 & 0.05 & $0.64 * * *$ & $0.69 * * *$ & $0.56^{* * * *}$ & $\mid-0.56^{* * * *}$ & $0.16^{* * *}$ & $0.22 * * *$ & $0.16 *$ & \begin{tabular}{|c|}
-0.08 \\
\end{tabular} & $\begin{array}{l}-0.09 \\
\end{array}$ & $0.16^{* * *}$ & 0.13 & $-0.20 * *$ & 0.06 & -0.15 & 1 & & & \\
\hline DEPOSITS & $\mid 0.11$ & 0.03 & $-0.43 * * *$ & $\mid-0.62 * * *$ & $\mid-0.52 * * *$ & $0.52 * * *$ & $\mid-0.30 * * *$ & $\mid-0.23$ & $\mid-0.29 * * *$ & 0.19 ** & $0.18^{* *}$ & -0.00 & -0.20 ** & $0.26 * * * *$ & -0.12 & $0.18^{* * *}$ & -0.87 **** & 1 & & \\
\hline NDF & $\mid-0.22 * * *$ & \begin{tabular}{|c|c|c|}
-0.11 \\
\end{tabular} & 0.09 & $0.36^{* * * *}$ & $0.34 * * *$ & 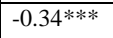 & $0.35^{* * * *}$ & \begin{tabular}{|l|l}
$-0.19^{* * *}$ \\
\end{tabular} & $0.35 * * * *$ & 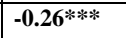 & 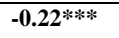 & $-0.16 * *$ & $0.22 * * * *$ & 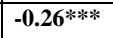 & $0.14 *$ & \begin{tabular}{|l|l|}
$-0.18 * * *$ \\
\end{tabular} & $0.51^{* * * * *}$ & $-0.86 * * * *$ & 1 & \\
\hline \begin{tabular}{|l|} 
SIZE \\
\end{tabular} & \begin{tabular}{|l|l|}
0.06 \\
\end{tabular} & 0.04 & $-0.46^{* * * *}$ & \begin{tabular}{|l|l|}
$-0.63 * * * *$ \\
\end{tabular} & -0.57 **** & $0.57^{* * * *}$ & -0.06 & $-0.39^{* * * *}$ & -0.05 & 0.07 & -0.07 & 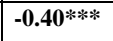 & \begin{tabular}{|l|l|}
$-0.15^{*}$ \\
\end{tabular} & $0.21^{* * * *}$ & 0.03 & 0.21 & $-0.77^{* * * * *}$ & $0.58 * * *$ & \begin{tabular}{|l|l|l|}
$-0.23 * * *$ \\
\end{tabular} & 1 \\
\hline
\end{tabular}

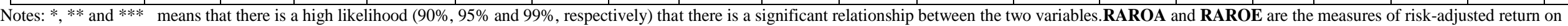
assets and on equity, respectively. Z-score is computed as the sum of ROA and the ratio of total equity to total assets divided by the standard deviation of ROA. IIN is computed as interest income divided by total operating income. NII is computed as non-interest income divided by total operating income. HHI_REV measures income diversification between IIN and NII (using the Herfindahl Hirschman Index). HHI_IIN measures the

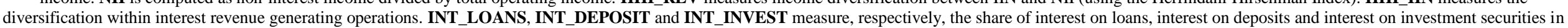

total interest revenue. HHI_NII measures the diversification within non-interest revenue generating operations. FEES, TRADE, INVEST, INSUR and FX measure the share of, respectively, fees generated from banking

operations, gains trading securities, profits from the sale of investment securities, fees and premium earned from taking or brokering insurance policy subscriptions and foreign currency trading gains in total non-interest

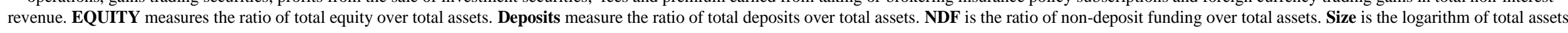


Non-interest income generating activities display different features. In fact, the mean value of HHI_NII of 0.467 indicates that there is a relative diversification within non-interest income activities for banks included in our sample. In terms of the composition of this type of bank revenue, fee based activities present a share of $52 \%$ in total non-interest income. This subcategory of non-interest income activities includes fees related to money transferring and check clearing, and other fees. However, and despite the observed relative diversification within non-interest income activities, we notice, at this stage of the analysis, that as long as these fees and commissions are generated from traditional banking operations through a crossselling of financial products to a core customer base, this would not lead to diversification benefits as income generated from fees earned from commercial banking operations are positively correlated with interest income 1 .

Table 1 shows interesting results regarding the funding structure of the banks included in this study. Indeed, on average, total assets of banks are funded by deposits from customers (72\%), non-deposit funding (17\%) and equity (11\%). We notice the large differences among banks regarding their capitalization as it is shown by the mean and the medina of the ratio of equity to total assets of $11.3 \%$ and $8.6 \%$, respectively. The mean of bank size is close to the median (7.6 compared to 7.7, measured using the logarithm of total assets) which ensures that our analysis is not suffering from a sample selection bias that may arise from sampling either large or small banks which would affect the diversification decision of bank revenue.

Table 1 shows a large disparity between banks in terms of efficiency as it is shown by the mean and the median levels. We notice that on average, one unit of revenue costs 0.535 units of non-interest expenses to banks.

Table 2 shows the pairwise correlation between the variables taken into consideration in this study. We notice that the diversification between interest income and non-interest income (as it is shown by the variable HHI_REV) is negatively and significantly correlated with risk-adjusted return on assets (RAROA) but positively and significantly correlated with bank stability (Z-Score). The first result indicates that a decrease in HHI_REV2 leads to higher risk-adjusted return on assets. This confirms the finding related to the relationship between income diversification and bank performance in emerging countries (Sanya and Wolfe, 2011). However, the second result indicates that an increase in diversification toward non-interest income (in other term a decrease in HHI_REV) leads to lower stability. Sanya and Wolfe (2011) find positive link between revenue diversification and bank stability in emerging economies.

The results for IIN and NII confirm the aforementioned interpretations. Indeed, Table 2 shows that NII (IIN) is significantly and positively (negatively) correlated with risk-adjusted performance but negatively correlated with bank stability.

The positive link between NII and risk-adjusted performance (RAROA and RAROE) is mostly driven by the positive correlation of these performance variables and non-interest income generated from investment securities (INVEST). One interesting result is that interest on loans to customers (INT_LOANS) is not correlated with risk-adjusted returns on assets (RAROA) and on equity (RAROE) which means that Tunisian banks are not generating much profit from their core business line (lending activity3).

As Table 2 shows that revenue diversification toward non-interest income is positively and significantly correlated with bank instability, we go further in our analysis through asking the question about which of the components of NII is driving this result. In fact, the pairwise correlation matrix shows that non-interest income generated from both fees on operations (FEES) and gains on trading securities (TRADE) which represent together a share of $63 \%$ of total non-interest income of Tunisian banks, are positively and significantly correlated with interest income (IIN). This interesting result explains the absence of the expected diversification benefit in term of bank stability. This is obvious since, in Tunisian banks, interest income generating activities are subject to the same fluctuations of non-interest income generating operations. Interestingly, the coefficient of correlation between the volume of interest income (IIN) and non-interest income (NII) is large (0.85)4. This means that most of non-interest income is generated from traditional banking activities through cross-selling financial product to a core business customer of banks.

Bank capitalization measured by the ratio of equity over total assets is positively correlated with bank stability. This is expected because well capitalized banks, through the pressure of their shareholders, are more risk-averse than under capitalized banks. Also, higher capitalization ratios allow banks to absorb losses and, therefore, reduce the overall risk. Equity ratio, however, is not correlated with risk-adjusted performance.

\footnotetext{
${ }^{1}$ A significant positive correlation of 0.62 .

${ }^{2}$ Notice that a decrease in HHI_REV means an increase in revenue diversification toward non-interest income, while an increase indicates an increase in revenue concentration on interest income.

3 Interest on loans to customers represents an average share of $66 \%$ of total operating income of Tunisian banks and a share of $96 \%$ of total interest income. 4 It is not reported in Table 2 as we only report the figures regarding correlations of IIN and NII in terms of shares in total operating income (in percentage but not in volume). We report in appendix 2 the matrix of pairwise correlation between interest and non-interest incomes and their components taken as volumes.
} 
TABLE 3

REGRESSION ANALYSIS RESULTS USING RANDOM EFFECTS REGRESSIONS

\begin{tabular}{|c|c|c|c|c|c|c|c|c|c|c|c|c|}
\hline \multirow[b]{2}{*}{$Y=$ Dependent variable } & \multicolumn{6}{|c|}{ Diversification between interest and non-interest income } & \multicolumn{6}{|c|}{ Diversification within both interest and non-interest income } \\
\hline & $\begin{array}{l}\text { RAROA } \\
\text { (1) }\end{array}$ & $\begin{array}{l}\text { RAROE } \\
(2) \\
\end{array}$ & $\begin{array}{c}\text { Z-SCORE } \\
(3)\end{array}$ & $\begin{array}{c}\text { RAROA } \\
\text { (4) }\end{array}$ & $\begin{array}{c}\text { RAROE } \\
(5) \\
\end{array}$ & $\begin{array}{c}\text { Z-SCORE } \\
(6)\end{array}$ & $\begin{array}{c}\text { RAROA } \\
(7) \\
\end{array}$ & $\begin{array}{c}\text { RAROE } \\
(8)\end{array}$ & $\begin{array}{c}\text { Z-SCORE } \\
(9)\end{array}$ & $\begin{array}{c}\text { RAROA } \\
(10) \\
\end{array}$ & $\begin{array}{c}\text { RAROE } \\
\text { (11) }\end{array}$ & $\begin{array}{c}\text { Z-SCORE } \\
(12)\end{array}$ \\
\hline \multirow[t]{2}{*}{ HHI_REV } & $-14.8 * * *$ & $-8.34 * * *$ & $-83.64 * * *$ & & & & & & & & & \\
\hline & $(2.464)$ & $(2.29)$ & (16.016) & & & & & & & & & \\
\hline \multirow[t]{2}{*}{ NII } & & & & $14.59 * * *$ & $7.37 * * *$ & $89.13 * * *$ & & & & & & \\
\hline & & & & $(2.084)$ & $(2.004)$ & $(13.377)$ & & & & & & \\
\hline \multirow[t]{2}{*}{ HHI_IIN } & & & & & & & -3.01 & $-4.48 * * *$ & -9.42 & & & \\
\hline & & & & & & & $(1.875)$ & $(1.576)$ & (12.17) & & & \\
\hline \multirow[t]{2}{*}{ HHI_NII } & & & & & & & $-3.33 * *$ & $-4.11 * * *$ & -1.89 & & & \\
\hline & & & & & & & $(1.328)$ & $(1.117)$ & $(8.628)$ & & & \\
\hline \multirow[t]{2}{*}{ INT_LOANS } & & & & & & & & & & -5.65 & -5.24 & 50.56 \\
\hline & & & & & & & & & & (6.712) & $(7.432)$ & $(37.440)$ \\
\hline \multirow[t]{2}{*}{ INT_DEPOSITS } & & & & & & & & & & 9.52 & -2.14 & $245.64 * * *$ \\
\hline & & & & & & & & & & $(12.88)$ & $(14.264)$ & $(71.857)$ \\
\hline \multirow[t]{2}{*}{ INT_INVEST } & & & & & & & & & & 13.04 & $15.64 *$ & $133.793 * * *$ \\
\hline & & & & & & & & & & (8.241) & $(9.125)$ & $(45.971)$ \\
\hline \multirow[t]{2}{*}{ FEES } & & & & & & & & & & $-3.63 * * *$ & $-2.11^{*}$ & $-18.67 * * *$ \\
\hline & & & & & & & & & & (1.016) & $(1.203)$ & $(6.061)$ \\
\hline \multirow[t]{2}{*}{ TRADE } & & & & & & & & & & $5.16 * * *$ & $3.01 * *$ & $24.29 * * *$ \\
\hline & & & & & & & & & & (1.157) & $(1.392)$ & $(7.013)$ \\
\hline \multirow[t]{2}{*}{ INVEST } & & & & & & & & & & $8.86 * * *$ & $5.11 * * *$ & $58.57 * * *$ \\
\hline & & & & & & & & & & $(1.016)$ & $(1.125)$ & $(5.669)$ \\
\hline \multirow[t]{2}{*}{ INSUR } & & & & & & & & & & $-6.67 * *$ & 4.22 & $-99.34 * * *$ \\
\hline & & & & & & & & & & $(3.279)$ & $(3.631)$ & (18.294) \\
\hline \multirow[t]{2}{*}{$\mathrm{FX}$} & & & & & & & & & & 2.60 & 2.91 & 13.279 \\
\hline & & & & & & & & & & (3.046) & $(3.373)$ & $(16.995)$ \\
\hline \multirow{2}{*}{ EQUITY } & 2.836 & -1.81 & $148.17 * * *$ & -0.43 & -3.84 & $131.13 * * *$ & -5.25 & $-7.37 * *$ & $112.33 * * *$ & -2.88 & -3.95 & 117.083 *** \\
\hline & $(3.172)$ & $(2.95)$ & $(20.618)$ & $(2.922)$ & (2.809) & $(18.751)$ & (3.376) & $(2.838)$ & $(21.923)$ & (2.435) & $(2.696)$ & $(13.582)$ \\
\hline \multirow[t]{2}{*}{ SIZE } & -0.359 & -0.36 & -1.20 & -0.54 & -0.42 & -2.49 & -0.34 & $-0.59 *$ & 0.89 & $-0.55^{*}$ & -0.41 & -2.38 \\
\hline & $(0.342)$ & $(0.318)$ & $(2.224)$ & $(0.335)$ & $(0.322)$ & $(2.149)$ & $(0.400)$ & $(0.336)$ & $(2.599)$ & $(0.842)$ & $(0.327)$ & $(1.650)$ \\
\hline \multirow{2}{*}{ EFFICIENCY } & $-5.44 * * *$ & $-6.47 * * *$ & $-14.97 * *$ & $-5.52 * * *$ & $-6.47 * * *$ & $-15.78 * *$ & $-5.74 * * *$ & $-7.37 * * *$ & -12.12 & $-5.55 * * *$ & $-6.08 * * *$ & -17.80 *** \\
\hline & $(1.043)$ & $(0.970)$ & $(6.784)$ & $(1.008)$ & $(0.969)$ & $(6.473)$ & $(1.188)$ & $(0.999)$ & $(7.717)$ & $(0.842)$ & $(0.932)$ & $(4.699)$ \\
\hline \multirow[t]{2}{*}{ GDP } & 0.101 & 0.10 & 0.21 & 0.095 & 0.10 & 0.18 & 0.54 & 0.05 & $0.97 *$ & 0.03 & 0.47 & -0.12 \\
\hline & $(0.075)$ & $(0.070)$ & $(0.489)$ & $(0.072)$ & $(0.070)$ & $(0.467)$ & $(0.832)$ & $(0.069)$ & $(0.540)$ & $(0.057)$ & $(0.063)$ & $(0.322)$ \\
\hline \multirow[t]{2}{*}{ INF } & -0.562 & -0.01 & -1.22 & -0.06 & 0.00 & -1.35 & 0.08 & 0.04 & -0.10 & 0.16 & 0.14 & 0.18 \\
\hline & $(0.146)$ & $(0.135)$ & $(0.949$ & $(0.140)$ & $(0.135)$ & $(0.902)$ & $(0.157)$ & $(0.132)$ & $(1.023)$ & $(0.110)$ & $(0.122)$ & $(0.616)$ \\
\hline Constant & $16.72 * * *$ & $12.91 * * *$ & $79.06 * * *$ & $5.37 *$ & $6.45 * *$ & 15.54 & $12.54 * * *$ & $16.76^{* * *}$ & 20.06 & $13.85 * *$ & 12.27 & -20.29 \\
\hline R-sq & 0.294 & 0.2805 & 0.5197 & 0.3404 & 0.2817 & 0.5627 & 0.1650 & 0.3046 & 0.4329 & 0.6199 & 0.4509 & 0.8095 \\
\hline
\end{tabular}


TABLE 4

\section{REGRESSION ANALYSIS RESULTS USING INSTRUMENTAL VARIABLES (2SLS) REGRESSION}

\begin{tabular}{|c|c|c|c|c|c|c|c|c|c|}
\hline \multirow[b]{2}{*}{$Y=$ Dependent variable } & \multicolumn{6}{|c|}{ Diversification between interest and non-interest income } & \multicolumn{3}{|c|}{ Diversification within both interest and non-interest income } \\
\hline & $\begin{array}{c}\text { RAROA } \\
\text { (1) }\end{array}$ & $\begin{array}{c}\text { RAROE } \\
\text { (2) }\end{array}$ & $\begin{array}{c}\text { Z- } \\
\text { SCORE } \\
(3) \\
\end{array}$ & $\begin{array}{c}\text { RAROA } \\
(4) \\
\end{array}$ & $\begin{array}{c}\text { RAROE } \\
(5)\end{array}$ & $\begin{array}{c}\text { Z- } \\
\text { SCORE } \\
(6) \\
\end{array}$ & $\begin{array}{c}\text { RAROA } \\
(7)\end{array}$ & $\begin{array}{c}\text { RAROE } \\
(\mathbf{8})\end{array}$ & $\begin{array}{c}\text { Z-SCORE } \\
(9) \\
\end{array}$ \\
\hline \multirow[t]{2}{*}{ HHI_REV } & $-17.4 * * *$ & $-9.78 * * *$ & $\begin{array}{c}- \\
100.51^{* *} \\
*\end{array}$ & & & & & & \\
\hline & $(3.03)$ & $(2.788)$ & $(19.780)$ & & & & & & \\
\hline \multirow[t]{2}{*}{ NII } & & & & $17.08^{* * * *}$ & $8.62 * * *$ & $\begin{array}{c}105.72 * * \\
*\end{array}$ & & & \\
\hline & & & & $(2.475)$ & $(2.360)$ & $(15.926)$ & & & \\
\hline \multirow[t]{2}{*}{ HHI_IIN } & & & & & & & -1.95 & $-4.30 *$ & -2.39 \\
\hline & & & & & & & $(2.511)$ & $(2.11)$ & $(15.84)$ \\
\hline \multirow[t]{2}{*}{ HHI_NII } & & & & & & & 1.13 & 0.31 & 14.57 \\
\hline & & & & & & & $(2.782)$ & $(2.342)$ & $(17.55)$ \\
\hline \multirow[t]{2}{*}{ EQUITY } & $7.35^{* *}$ & 0.94 & $\begin{array}{c}165.31 * * \\
*\end{array}$ & 3.41 & -1.54 & $\begin{array}{c}144.53 * * \\
*\end{array}$ & -0.13 & -2.86 & $126.28 * * *$ \\
\hline & $(3.677)$ & $(3.338)$ & $(23.981)$ & $(3.300)$ & $(3.147)$ & $(21.237)$ & $(4.251)$ & $(3.579)$ & $(3.421)$ \\
\hline \multirow[t]{2}{*}{ SIZE } & -0.10 & -0.17 & -0.39 & -0.32 & -0.26 & -1.86 & 0.42 & 0.12 & 3.62 \\
\hline & $(0.363)$ & $(0.334)$ & $(2.370)$ & $(0.355)$ & $(0.338)$ & $(2.283)$ & $(0.542)$ & $(0.456)$ & $(3.421)$ \\
\hline \multirow[t]{2}{*}{ EFFICIENCY } & $-5.04 * * *$ & $-6.22 * * *$ & $-14.99 * *$ & $-5.12 * * *$ & $-6.24 * * *$ & $-15.71 * *$ & $-4.44 * * *$ & $-6.18 * * *$ & -8.86 \\
\hline & $(1.077)$ & $(0 . .990)$ & (7.028) & $(1.038)$ & $(0.990)$ & $(6.684)$ & $(1.456)$ & $(1.225)$ & $(9.187)$ \\
\hline \multirow[t]{2}{*}{ GDP } & 0.09 & 0.10 & 0.20 & 0.08 & 0.09 & 0.16 & 0.08 & 0.08 & 0.25 \\
\hline & $(0.073)$ & $(0.133)$ & $(0.480)$ & $(0.071)$ & $(0.067)$ & $(0.457)$ & $(0.086)$ & $(0.072)$ & $(0.545)$ \\
\hline INF & $\begin{array}{c}-0.10 \\
(0.145)\end{array}$ & $\begin{array}{c}-0.03 \\
(0.133) \\
\end{array}$ & $\begin{array}{c}-1.52 \\
(0.948) \\
\end{array}$ & $\begin{array}{c}-0.11 \\
(0.138) \\
\end{array}$ & $\begin{array}{c}-0.02 \\
(0.132)\end{array}$ & $\begin{array}{l}-1.67 * \\
(0.894) \\
\end{array}$ & $\begin{array}{c}0.16 \\
(0.164) \\
\end{array}$ & $\begin{array}{c}0.12 \\
(0.138)\end{array}$ & $\begin{array}{c}0.13 \\
(1.040) \\
\end{array}$ \\
\hline Constant & $15.85^{* * *}$ & $12.02 * * *$ & $82.23^{* * * *}$ & 2.53 & 4.54 & 5.45 & 1.96 & 7.45 & -19.77 \\
\hline $\mathrm{R}$-sq & 0.303 & 0.2929 & 0.4964 & 0.3529 & 0.2936 & 0.5446 & 0.1144 & 0.2461 & 0.4006 \\
\hline
\end{tabular}




\section{EMPIRICAL RESULTS}

Table 3 shows our empirical results using random effects models. We have twelve specifications where we examine the relationship between bank income diversification across interest and non interest income generating activities as well within these two types of revenue on bank performance and stability. In specification 1-3, we examine the link between revenue diversification and bank performance and stability using as proxy for diversification the index HHI of both main categories of income (interest and non-interest income).

In specification 4-6, we use one direct measure of diversification which is NII (non-interest income over total operating income). In specification 7-9, we try to examine the effects of diversification within both interest and non-interest income on bank performance and stability using the index HHI. In last specification 10-12, we examine the relation between each component of interest and non-interest income and bank performance and bank stability.

In all specification, we find that revenue diversification across and within interest and non-interest income enhance bank performance and stability. Notice that the negative coefficient oh HHI _REV means that an increase in diversification towards non-interest income (in other words a decrease in HHI-REV) is associated with an increase in risk-adjusted return on assets (RAROA) and on equity (RAROE) as well as in bank stability measured by Z-Score. The same reasoning is for HHI_IIN and HHI_NII. These results confirm our hypotheses which state that when banks shift towards non-interest income generating activities, their performance and stability improve.

The positive impact of revenue diversification on bank performance can be explained by the fact that when banks diversify their income structure by exploring new business lines, their innovation and competitiveness increase which leads to higher profitability. On the other hand, the positive impact of revenue diversification on bank stability can be explained by the fact that when banks shift toward non-interest generating activities the volatility of their income decreases as their interest and non-interest incomes are not perfectly correlated.

Our results show that the impact of income diversification toward non-interest revenue generating operations does depend on the category of non-interest revenue as well as its correlation with interest revenue and its subcategories. We found the diversification gains to be more pronounced when banks shift to non-interest income generating activities that are not correlated with interest income and are stemming from nontraditional banking activities. This is explained by the fact that nontraditional banking operations are not subject to the same fluctuations as interest-generating operations. This lowers earnings volatility and improves stability. Unsurprisingly, non-interest income stemming from traditional banking activities worsens bank stability.

In all specification, we find that revenue diversification across and within interest and non-interest income enhance bank performance and stability. Notice that the negative coefficient oh HHI _REV means that an increase in diversification towards non-interest income ( in other words a decrease in HHI-REV) is associated with an increase in risk-adjusted return on assets (RAROA) and on equity (RAROE) as well as in bank stability measured by Z-Score. The same reasoning is for HHI_IIN and HHI_NII. These results confirm our hypotheses which state that when banks shift towards non-interest income generating activities, their performance and stability improve.

The positive impact of revenue diversification on bank performance can be explained by the fact that when banks diversify their income structure by exploring new business lines, their innovation and competitiveness increase which leads to higher profitability. On the other hand, the positive impact of revenue diversification on bank stability can be explained by the fact that when banks shift toward non-interest generating activities the volatility of their income decreases as their interest and non-interest incomes are not perfectly correlated.

Our results show that the impact of income diversification toward non-interest revenue generating operations does depend on the category of non-interest revenue as well as its correlation with interest revenue and its subcategories. We found the diversification gains to be more pronounced when banks shift to non-interest income generating activities that are not correlated with interest income and are stemming from nontraditional banking activities. This is explained by the fact that nontraditional banking operations are not subject to the same fluctuations as interest-generating operations. This lowers earnings volatility and improves stability. Unsurprisingly, non-interest income stemming from traditional banking activities worsens bank stability. 


\section{CONCLUSION}

In this study we use a detailed dataset on eleven banks operating in Tunisia over the period 2001-2014 to examine the relationship between revenue diversification and bank performance and stability. Using a panel data estimation as well as instrumental variables approach (2SLS) to handle the endogeneity problem of diversification variables, we find that income diversifications between and within interest and non-interest income generating activities enhance bank performance and bank stability.

Our findings confirm those of previous studies on emerging banking sectors. For instance, over the period 2001-2014, Tunisian banks show a relative large reliance on interest income generating activities (62\%) which is made mainly through interest on loans to customers with a share in total interest income of 96\%. Also, like in developing countries (Sanya and Wolfe, 2011), our findings suggest that banks benefit from a better revenue diversification. In fact, the diversification of income structure leads to better trade-off between the expected level and variance of banks' performance. Of course, for this positive effect of revenue source diversification to hold, banks' income-generating operations should not be perfectly correlated. Also, the positive effect of revenue diversification toward non-interest income generating activities can be explained by its role in lowering the cyclical variations in profits if incomes between bank activities are not perfectly correlated. This in addition to the role played by income diversification in increasing competitive pressures between banks across a large number of banking business lines which can increase innovation and efficiency in the provision of banking services.

The results also indicate that diversification gains are largest for banks with more shifts to nontraditional banking business lines while, absent for banks which follow cross-selling strategies of financial services.

Furthermore, our results show that the effect of revenue diversification does depend on the category of non-interest revenue and its correlation with interest revenue and its components. In fact, we found the diversification gains to be more pronounced when banks shift to non-interest income generating activities that are not correlated with interest income and are stemming from nontraditional banking activities such as investment banking and fee-based income from nontraditional operations (like for example commissions, fees and premiums earned from insurance activity).

One explanation of this result is that nontraditional banking operations are not subject to the same fluctuations as interestgenerating operations which leads to lower earnings volatility. However, non-interest income coming from traditional banking activities worsens bank stability.

This study can be extended in several directions. One way for future researches would be to explore more channels through which revenue diversification can affect bank performance and stability. One channel would be the improved banking competition and innovation in presence of income diversification.

\section{REFERENCES}

[1] Ahmad, M; M. (2017). : “Asset quality, non-interest income, and bank profitability: Evidence from Indian banks. Economic Modelling. Vol. 63, pp. 1-14.

[2] Altunbas, Y; Manganelli, S and Marques-Ibanez, D, (2011): "Bank Risk During the Financial Crisis - Do Business Models Matter?". ECB Working Paper Series, $N^{\circ} 1394$, European Central Bank, Frankfurt.

[3] Ayadi, R ; Arbak, E and de Groen, W.P, (2011) : «Business Models in European Banking: A Pre-and Post-Crisis Screening”. Centre for European Policy Studies, Brussels.

[4] Belaid, F and Bellouma, M, (2016): "Determinants of loan quality: evidence from the Tunisian banking sector". International Journal of Engineering Research \& Science. Vol 2. P, 67-79.

[5] Beltratti, A and Stulz, R.M, (2012) : «The credit crisis around the globe: why did some banks perform better?". Journal of Financial Econ. Vol 105 (1).P, 1-17.

[6] Busch, R. and Kick. T, (2009): "Income Diversification in the German Banking Industry". Bundes bank Discussion Paper, N 09/2009.

[7] Chen, Y; Liu, Jun Su (2013) ; «Greasing the wheels of bank lending: Evidence from private firms in China.” Journal of Banking \& Finance, Vol.37( 7), P, 2533-2545.

[8] Chiorazzo, V. Milani, C and Salvini, F, (2008): "Income diversification and bank performance: evidence from Italian banks. Journal of Financial Services Research. Vol 33. P.181-203.

[9] DeYoung, R and Torna, G (2013): "Nontraditional banking activities and bank failures during the financial crisis". Journal of Financial Intermediation. Vol 22. P,397-421.

[10] Demirgüc-Kunt, A and Huizinga, H, (2010): "Bank Activity and Funding Strategies: The Impact on Risk and Returns", Journal of Financial Economics, Vol. 98, pp. 626-650. 
[11] Delis, M.D., Hasan, I and Tsionas, E.G, (2014): “The risk of financial intermediaries”. Journal of Banking and Finance. Vol 44. P, 112.

[12] Diamond, D.W and Rajan, R.G, (2001): "Liquidity risk, liquidity creation, and financial fragility: a theory of banking". Journal of Political Economie. Vol 109 (2). P, 287-327.

[13] ECB, (2010): "EU Banking Structure Report”, European Central Bank, Frankfurt.

[14] Foos, D; Norden L. and Weber, M, (2010): "Loan Growth and Riskiness of Banks", Journal of Banking and Finance, Vol. 34(12). P, 2929-2940.

[15] Imbierowicz, B, and Rauch, C, (2014): "The relationship between liquidity risk and credit risk in banks. Journal of Banking and Finance, Vol. 40. P, 242-256.

[16] Jimenéz, G and Saurina, J, (2006): “Credit Cycles, Credit Risk, and Prudential Regulation”. International Journal of Central Banking. Vol. 2(2).P, 65-98.

[17] Köhler, M, (2015): "Which banks are more risky? The impact of business models on bank stability". Journal of Financial Stability. Vol. 16. P, 195-212.

[18] Laeven, L. and Levine, R, (2009): "Bank governance, regulation and risk taking”. Journal of Financial Economics. Vol. 9. P, 259-275.

[19] Lepetit, L; Nys, E ; Rous, P and Tarazi, A, (2008) : «Bank income structure and risk: an empirical analysis of European banks". Journal of Banking and Finance. Vol.32. P, 1452-1467.

[20] Liikanen, E, (2012): "High-Level Expert Group on Reforming the Structure of the EU Banking Sector".

[21] Martín-Oliver, A; Ruano, Sand Salas-Fumás, V, (2015): "The Fall of Spanish Cajas: Lessons of Ownership and Governance for Banks".

[22] Mehran, H and Thakor, A.V, (2010): “Bank capital and value in the cross-section” Rev.Financ. Stud. Vol. 24 (4).P, $1019-1067$.

[23] Mercieca, S; Schaeck, K and Wolfe, S, (2007): “Small European banks: benefits from diversification?". Journal of Banking and Finance. Vol. 31. P, 1975-1998.

[24] Mergaerts, Fand Vennet, R. V, (2016): "Business models and bank performance: A long-term perspective". Journal of Financial Stability. Vol. 22.P, 57-75.

[25] Meslier, C; Tacneng, R and Tarasi, A, (2014): "Is bank income diversification beneficial? Evidence from an emerging economy". Journal of International Financial Markets, Institutions \& Money. Vol. 31. P, 97-126.

[26] Maudos, J and Solis, L (2009): "The determinants of net interest income in the Mexican banking system: an integrated model". Journal of Banking and Finance. Vol. 33. P, 1920-1931.

[27] Nguyen, M, Skully, M and Perera, S,(2012):"Market power, revenue diversification and bank stability: Evidence from selected South Asian countries". Journal of International Financial Markets, Institutions and Money. Vol. 22. P, 897-912.

[28] Pennathur, A.K; Subrahmanyam, V and Vishwasrao, S,(2012): "Income diversification and risk: does ownership matter? An empirical examination of Indian banks". Journal of Banking and Finance. Vol. 36. P, 2203-2215.

[29] Roengpitya, R., Tarashev, N., Tsatsaronis, K, (2014): "Bank business models". BIS Q. Rev. P, 55-65.

[30] Sanya, S and Wolfe, S, (2011): "Can banks in emerging economies benefit from revenue diversification?" Journal of Financial Services Research. Vol. 40.P, 79-101.

[31] Schaeck, K and Cihak, M, (2012): "Banking competition and capital ratios”. European Financial Management. Vol. 18(5). P, 836866.

[32] Stiroh, K.J, (2004a): “Do community banks benefit from diversification?” Journal of Financial Service Research. Vol. 25. P, 135-160.

[33] Stiroh, K.J, (2004b): “Diversification in banking: is non-interest income the answer?". Journal of Money, Credit and Banking. Vol. 36. P, 853-882.

[34] Stiroh, K. J, (2006): "New evidence on the determinants of bank risk". Journal of Financial Service Research. Vol. 30. P, $237-263$.

[35] Stiroh, K. J and Rumble, A, (2006): "The dark side of diversification: the case of U.S financial holding companies". Journal of Banking and Finance. Vol. 30. P, 2131-2161. 